\title{
咬合小面の傾斜角度測定装置
}

\author{
村 松 篤 良 \\ 東京医科菌科大学菌科材料研究所 \\ 石原壽 郎尾花㴹一。 \\ 東京医科菌科大学補経学教室 (主任 中沢教授)
}

\section{A New Type of Optical Protoractor}

\author{
Atsuyoshi Muramatsu \\ Research Institute of Dental Materials, Tokyo Medical and Dental University \\ Toshiro Ishiwara and Jinichi Obana \\ Department of Prosthetic Dentistry, Tokyo Medical and Dental University \\ (Prof. I. Nakazawa)
}

The authors deviced a new type of optical protoractor, an apparatus for measuring the angle of functional cusp inclination. By the ward of functional cusp inclination the authors mean the slope of small surfaces of occlusal wearing, which harmonizes with mandibular movements.

This apparatus consists of two parts, an optical system and a special protoractor. Through the semitranslucent mirror a parallel light beam is thrown vertically upon specimen, which is attached on the circular stage of protoractor. By the angulation of maximum reflection of light, the angle of cusp inclination can be determined three dimensionally. Very small area even $1 \mathrm{~mm}^{2}$ can be measured easily and accurately with this apparatus.

Average error of measurements is estimated $\pm 0.5^{\circ}$ for the angle of inclination and $\pm 2.0^{\circ}$ for that of direction.

\section{I 緒 言}

㐘牙咬合面形態は種々な立場から研究されつ〉 㟧るが, 中でも咬頭傾刹角度の問題は顎運動, 咀 嚼能率などの機能的な面から補緅学上最も重要視

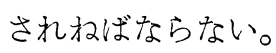

既に Gysi (1910), 矢犄 (1929), その他によつ て咬頭傾科角度の実测とその意味づけが行われた が，测定法は分度器などを直接咬合面にあて子行 万簡単なるのであつた。従つて咬合面に現れる立 体的な角度を平面的なるのとして取报つて抢り，

本論交の要旨は昭和 27 年度日本米科医師会学術会 議補綴学部会に招いて発表した。
测定位置も不明確であるため测定值の意味乞のる のが懓昧であり, 咬頭の傾斜角度を合理的に現わ すものではなかつた。元来，咬頭は曲面をなして いるので一定の傾科角を考学ることは困難である が, 通常, 青年期以上のものでは咬頭の斜面上に 㖫耗によつてや〉平面に近い削隦面ができてい る。我々はこの咬耗面が咬合及び顎運動に協調し てできた機能的な㖫合小(局)面であり，その傾斜 角度が機能的な意味で真の焧頭傾斜角度と解釈す べきものと考光ている。㖫合小面は㕌 $1 \mathrm{~mm}^{2}$ 程 度の微小な面䅡を示すこともあるので，上記の方 法では全く测定することが出来ない。そこで我々 は光学的测测定する装置を考案し, 容易且つ正確 
に目的を達しらるようになつたのでその概要を述 ベることにする。

\section{II 測定裝置の構造及び特徵}

㖫合小面に緗い平行光線を投射し，乞の反射光 量が最大となる位置を 2 倜の角度目盛板によつて 测定するものであつて，光源装置と测定台からな つている(図 1 )。

1) 光源装置 (図 2 参渠)。光源装置の主体は 金属製で，光源(図 2-A), 集光レンズ(図 2-B), 半逶明平面鏡 (図 2-C), 観测简 (図 2-D), 基底

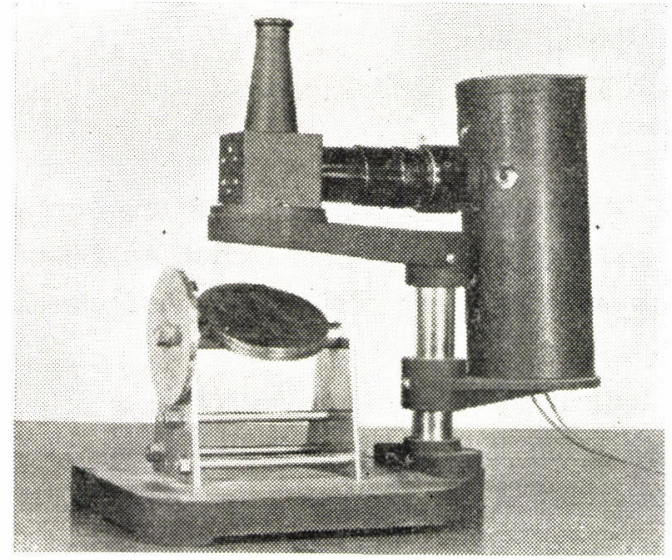

図 1 咬合小面角度測定装置

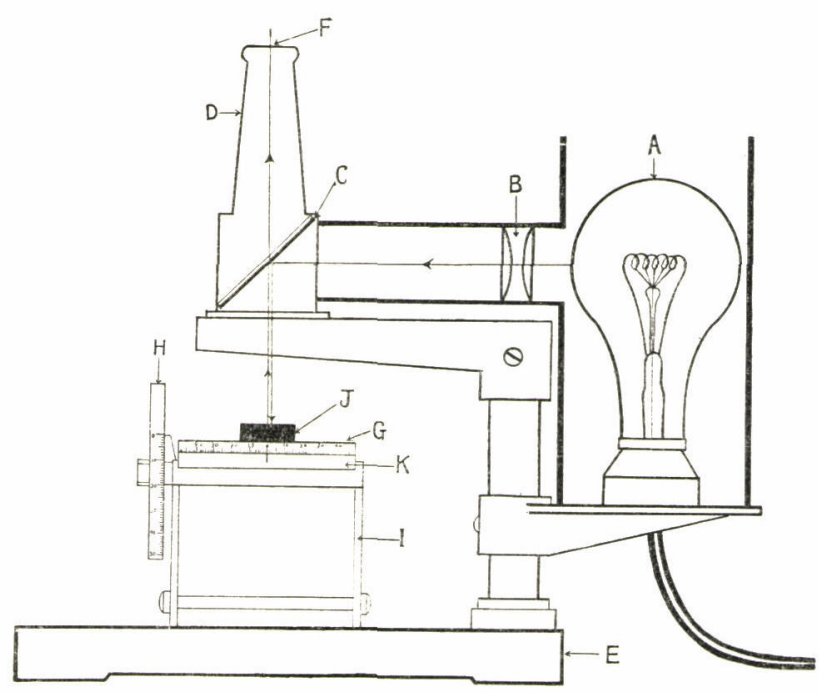

図 2 測定装置の構造
部(図 2-E)の 5 部からなり, 光源に $200 \mathrm{~W}$ 電球, 集光レンズは径 $5 \mathrm{~cm}$ の凸レンズである。半逶明 平面鏡は金メッキが施された $4 \mathrm{~cm}^{2}$ の鏡である。 これに図 2-C の如くメッキ面を光源に向け，基 底面及びレンズに対し $45^{\circ}$ の角度に固定され，乞 の周国に光線の通る部分を除きすべて䍩消しの黒 色塗料で内面を塗つた箱で被覆し遮光してある。 長さ約 $8 \mathrm{~cm}$ の観测筒に气の上部中尖に直径約 1.5 $\mathrm{mm}$ の観测孔(図 2-F) があり，半透明平面鏡を 通じて被検物をのでくようになつている。又, 視 学を除くために中央に十字の標識を設けたが，実 際の测定には乞の必要は㱠んどなく却つて観测を 困難にしたので廃止した。基底部に約 $23 \mathrm{~cm}^{2}$ の 一平面を有し，乞の表面に测定台の移動を容易に するため仕上げ研磨されている。

2) 测定台。测定台に水平目盛板(図 $2-G$ ), 垂 直目盛板 (図 $2-\mathrm{H}$ ), 及心゙脚 (図 $2-\mathrm{I}$ ) から出来て いる。水平目盛板に被検物(図 $2-\mathrm{J}$ ) 兄のせる直径 $10 \mathrm{~cm}$ の板でその周囲测面に, 左右これぞれ $0^{\circ}$ から $180^{\circ}$ までの目盛が刻印され基板(図 $2-\mathrm{K}$ )の 上で自明に回転しうるようになつている。又，基 板は光源装置の基底部に平行な軹学中心にして回 転させることが可能で，その角度は垂直目盛板に 刻まれた $0^{\circ}$ から $90^{\circ}$ の目盛によつて知ることが でき, 垂直目盛板が 0 のとき基板及び水平 目盛板々基底面と平行になるようにして市 る。従つて被榆物は直交する2つの軸を中 心にして自且に廻転して空間的に自由な位 置をとらせることが出来, 乞の角度に 2 侗 の目盛板によつて测定されるわけである。 测定台の脚は光源装置の基底面上を容易に 移動しうるよう, 重量の軽減と磨擦を最少 限に止ぶるるべく䌘作した。

3) 特 徴

唼合小面の角度深これを2つの要素に分 析してはじめて補経学的な意味が明かにな るもので，この装置で测定しょうとするの ほ次の 2 つの角度である。第 1 は基準面 (例觉济咬合平面) と㖫合小面のなす面角, これは基準面に対する傾きを示すから傾斜 
角と呼ぶ。第 2 は咬合小面の向いている方向でこ れを方位角と呼び，基蕉線(例光ば正中線)に対す る角度であらわす。

分度器を用いる従来の方法では, 咬合小面に分 度器をあてた方向に切断して得られた直線の角度 を知りらるに過ぎない。従つて同一傾斜角の小面 でも方位角の違いによつて異つた傾斜をもつもの と判定されることになるから，䓕だ不合理な結果 となる。

我々の装置は上記の目盛板によつて傾斜角と方 位角の 2 要素を测定しうるから，これによつてほ じめて咬合小面の傾斜を立体的に現すことが出来 る。又, 分度器による方法で㖫合小面の傾斜を正 確に测るためには或る程度の広さを要するが，こ の装置は光の反射を利用していらから 約 $1 \mathrm{~mm}^{2}$ までの小面の傾斜を容易に测定することが出来 る。但し，咬合小面に一般に若千の彎曲を示し完 全な平面でないから，测定值にバラッキの出るこ ともあるが， $2 \sim 3 \mathrm{~mm}^{2}$ 程度の 小面積であるか らこの点は大した問題ではない。彎曲度のつよい

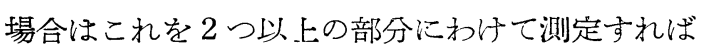
よいのである。

\section{III 測定方去}

被検物を测定台の定位置にニーテリテーワック スなどで確実に固定し，光源装置の基底面中央に 置く。被検物は主として石霄模型で测定面に墨汁 を塗布し, 反射效果を上げるために乾燥後セル口 イドを醋酸アミールに溶かしたものを平均に狳布 して持く。さて测定は観测を容易にし数值の正確 を期するために, 外部からの光線を遮断した喑室 で行らが，簡単な大型暗箱を使用しても実際には さしつかえない。

光源からの光は集光レンズを通つて平行光線と なり，半透明平面鏡によつて直角に屈曲乙基底面 に垂直に投射される。こっで测定台を气の直下に 移動しつ〉测定すべき咬合小面上に乞の光を市て その反射光を観察するのである。咬合小面が光軸 に垂直，即ち基底面に平行になつたとき反射光に 最も明るくなるわけであるから，测定台の 2 個の 角度目盛板を廻転, 調節してその位置を求めそれ
ぞれの角度をよみとる。垂直目盛板に示された数 值は咬合小面の基底面に対する傾斜角を示し，水 平目盛板に示された角度は㖫合小面の方位角を示 すものである。

\section{IV 精 度}

测定に先立ち予め光源装置の検討と测定台の精 度测定などを次の方法で行い测定值の正確を期し た。光源装置についてにその各部が設計通りに製 作されているか否かの検討を行つた。特に光源々 集光レンズの位置に自由に調節しうるよう作られ ているので，基底面中央に墨汁を平均に塗布した 小型の平面ガラス板を置き， 2 個の角度目盛を $0^{\circ}$ とした時の最大反射光量を求め固定した。な拈光 源と集光レンズの位置的関係が装置の主要な役目 を持つているので, その都度裥正を行ら必要が市 宁。

1）测定台の精度

测定台の 精度测定は 1/100 mm ダイヤルゲージ で行い，先ずa)垂直目盛板を $0^{\circ}$ に置き水平目盛 板を迴転した時の円板の上下方向の誤器，及びb) 垂直目盛板を廻転した時の上下方向の誤等，を测 定すれば任意な面を测定值の精度を判定すること が出来る。a)の場合, 水平目盛板の中心よりの距 離 $30 \mathrm{~mm}$ より $5 \mathrm{~mm}$ 怙きに $45 \mathrm{~mm}$ まで 4 点に ついて，また水平目盛板の廻転を右または左迴 りに $45^{\circ}$ 扣きに测定を行つたところ円周に近い点 で最大 $2^{\prime}$ の誤発であつた。b) の場合，水平目盛 板の中心より距離を $10 \mathrm{~mm}$ より $5 \mathrm{~mm}$ 打きに 45

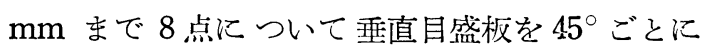
测定したところ, 円周に近い点で最大 $10^{\prime}$ の誤善 であつた。な打水平目盛板の中心よりの距離でそ の鉛直方向の長さを割れば，近似的にその点の角 変位を知ることが出来る。上述の角度の数值にこ の意味である。

\section{2）三角杜体によっ精度测定}

綜合的に装置全体として実際にどの程度の精度 があるか実験を行つた。実験に使用した被検物に 面角が $18^{\circ}, 29^{\circ}, 44^{\circ}$ の 3 個の硬不霄製三角柱体を 角度定規を用いて出来るだけ正確に製作し，测定 面に墨汁を塗布, 乾燥後稀薄なセルロイド溶液を $2 \sim 3$ 回毛筆で塗布し反射を良好ならしめた。测 


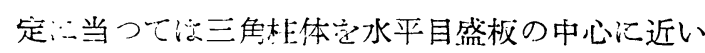
部分, 川夙に近い部分, 乞の中間位置と 3 カ所に二 ーテリテーワックスで仮着し，その方位角を種々 変化させて测定を行つたところ，傾斜角の誤善は 最大 $\pm 0.5^{\circ}$ で方位角の最大誤若は $\pm 2.0^{\circ}$ を示 した。これらの誤落は三角柱体製作時の寸法俱差 或は测定誤荎ではないかと思われる。なおこの実 験によつて直接分度器をあてつ正確に测定するこ とがいかに困難であるから゙推察された。従つてこ の程度の誤装に咬合小面の角度测定に重大なる影 響を及ぼすものと汸考えられない。

3）方位角の测定愦筀と傾斜角の関係

前述した傾斜角と方位角にそれぞれ密接な関係 を有し，傾斜角の変化によつて方位角の测定誤差 がどの程度生ずっかについても明かにする必要が 㐫る。この実験汇被検物として小さな平面ガラ ス板を用い，乞の中尖に的 $2 \mathrm{~mm}^{2}$ の反射面を作 り测定を行つた。乞の結果図 3 の如く傾斜角が減 少するに從い方位角の测定愦拻徐々に増加する

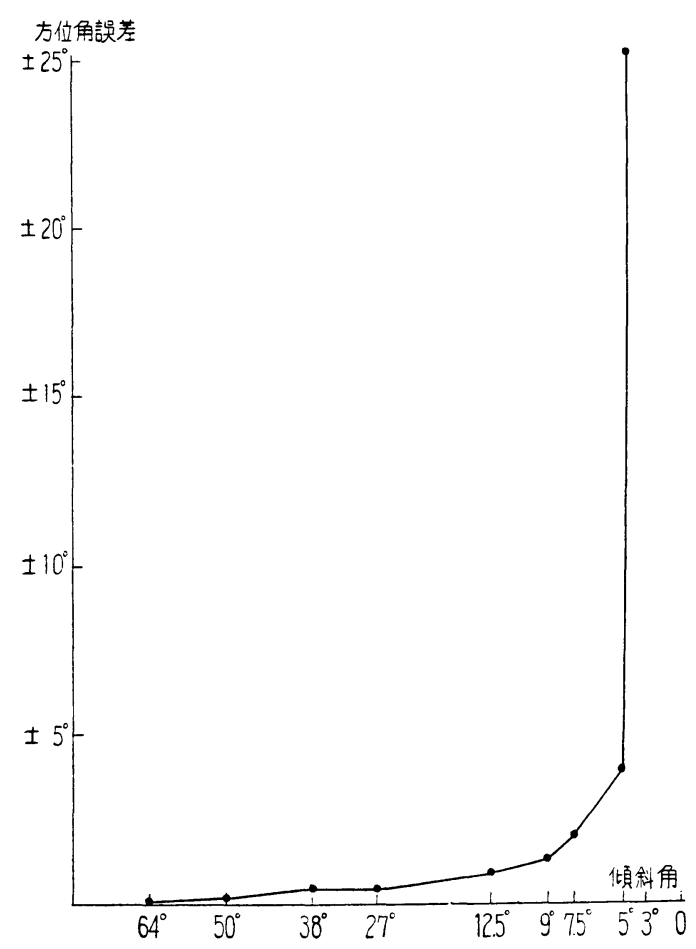

困 3 方位角の測定誤差と倾斜角の関係
傾向にあり，傾斜角 $10^{\circ}$ までは方位角の誤若は最 大 $\pm 1.0^{\circ}$ であるが，傾斜角 $7.5^{\circ}$ から方位角の 誤荎は急激に增大乙, 傾科角 $3^{\circ}$ で $\pm 25.0^{\circ}$ を示 した。この実験では資料の関係でこれ以下の测定 は行えなかつたが当然方位角の愦兴は倍加され, 幾何学的にいつて 傾斜角が $0^{\circ}$ のとき誤差は $360^{\circ}$ となるのである。この結果から みると傾斜角 $5^{\circ}$ 以下では方位角の誤空が極めて大きいので数值そ のものを信ずることは出来ないが，咬合小面の傾 斜角が $5^{\circ}$ 以下の場合は錸めて稀れであること〉， その際，方位角が多少移動しても傾斜角乞のもの に大きな変化を与劣るものではない。

\section{$\mathbf{V}$ 結 論}

1）㖫合小面の傾斜角度を光学的に测定し5る 装置を考案し，はじめて正確な傾科角度を表現し らるならになつた。

2）测定装置に光源装置と测定台の 2 部からな り，平行な反射光量の最大となる点を観测して 2 つの角度を求める構造を有する。

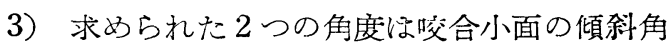
と方位角を現わすもので，これによつてはじめて 咬合小面を立体的なものとして計测しうる。

4）被検物は主として硬石等模型で, 测定面の 反射效果を上げるため，墨汁と稀薄なセロイド溶 液を平均に塗布したものを用うる。

5）約 $1 \mathrm{~mm}^{2}$ までは面積の小さな程，容易に 確実な测定が出来, 多少の曲面でも测定は可能で あっ。

6）测定台の精度は最大誤管 $10^{\prime}$ に過ぎず極め て正確である。

7）硬石管製三角柱体による装置全体の精度は 傾科角の最大䛊等 $\pm 0.5^{\circ}$, 方位角は $\pm 2.0^{\circ}$ である。

8）傾斜角が $10^{\circ}$ までは方位角の最大誤荎は土 $1.0^{\circ}$ で $5^{\circ}$ 以下になると方位角の誤芸は急激に増 大乙傾斜角 $3^{\circ}$ で $\pm 25.0^{\circ}$ となるが，咬合小面の 测定には殆んど影響がない。

\section{文献}

1) Gysi, A.: The problem of articulation, D. Cosmos LII : 148, 1910.

2) 篠出, 井形: 精密測定学, 東京, 炤 24 . 日本評 論社. 60 頁.

3) 矢崎正方：下鶜運動の 解剖学的研究特に咀嚼能 率に炎ぼす関係について(其の 2 ), 柬科学報 34 : $590,1929$. 